\title{
PENGEMBANGAN LEMBAR KERJA SISWA (LKS) BERBASIS CONTEXTUAL TEACHING AND LEARNING DI LINGKUNGAN SEKOLAH PADA MATA PELAJARAN IPA KELAS III SD MUHAMAMDIYAH PAKEL PROGRAM PLUS YOGYAKARTA
}

\author{
Brahmantara Insan $\mathbf{P}^{1}$, Panji Hidayat ${ }^{2}$ \\ PGSD FKIP Universitas Ahmad Dahlan \\ bramip18@gmail.com
}

\begin{abstract}
The research background is caused by students tend to feel bored when learning science. This study aims to develop LKS teaching materials based on Contextual Teaching and Learning in the school environment for science subjects for grade III elementary school, and to determine the feasibility of LKS teaching materials based on Contextual Teaching and Learning developed. This study uses the Research and Develpoment $(R \& D)$ method which was adapted from Sugiyono's research. The teaching materials developed through media expert validation, material expert validation, and learning expert validation. Then it was tested at Pakel Muhammadiyah Elementary School Yogyakarta Plus Program by using small group and large group trials. The research was carried out in accordance with the planned steps, in accordance with the development model adapted from Sugiyono's research, resulting in Contextual Teaching and Learning-based LKS teaching materials in the school environment on science subjects material for maintaining environmental health around class III SD Muhammadiyah Pakel Plus Program Yogyakarta, learning can be more effective. The evaluation data for teaching materials developed are as follows: media experts get a percentage of $93.3 \%$ in very decent criteria, material experts get a percentage of $81.67 \%$ in very feasible criteria, learning experts get a percentage of $80 \%$ in eligible criteria, small group trials the percentage of $91.1 \%$ is very feasible, the large group trial gets a percentage of $97.82 \%$ which is very feasible, the assessment of the small group trial teacher gets a percentage of $98.3 \%$ and is very feasible, and the assessment of large group testing teachers get a percentage of $100 \%$ which is very feasible. Based on these data, LKS teaching materials based on Contextual Teaching and Learning developed are appropriate for use in the learning process.
\end{abstract}

Keywords: Student, Contextual, Science, Worksheets.

\begin{abstract}
ABSTRAK
Latar belakang penelitian disebabkan siswa cenderung merasa bosan saat pembelajaran IPA. Penelitian ini bertujuan untuk mengembangkan bahan ajar LKS berbasis Contextual Teaching and Learning di lingkungan sekolah pada mata pelajaran
\end{abstract}


IPA untuk kelas III SD, dan untuk mengetahui kelayakan dari bahan ajar LKS berbasis Contextual Teaching and Learning yang dikembangkan. Penelitian ini menggunakan metode Research and Develpoment (R\&D) yang diadaptasi dari penelitian Sugiyono. Bahan ajar yang dikembangkan ini melalui validasi ahli media, validasi ahli materi, dan validasi ahli pembelajaran. Kemudian diujicobakan di SD Muhammadiyah Pakel Program Plus Yogyakarta dengan menggunakan uji coba kelompok kecil dan kelompok besar.

Penelitian yang dilakukan sesuai dengan langkah-langkah yang direncanakan, sesuai dengan model pengembangan yang diadaptasi dari penelitian Sugiyono, sehingga dihasilkan bahan ajar LKS berbasis Contextual Teaching and Learning di lingkungan sekolah pada mata pelajaran IPA materi menjaga kesehatan lingkungan sekitar kelas III SD Muhammadiyah Pakel Program Plus Yogyakarta, pembelajaran dapat menjadi lebih efektif. Data penilaian bahan ajar yang dikembangkan adalah sebagai berikut: ahli media mendapat persentase 93,3\% masuk kriteria sangat layak, ahli materi mendapat persentase $81,67 \%$ masuk kriteria sangat layak, ahli pembelajaran mendapat persentase $80 \%$ masuk kriteria layak, uji coba kelompok kecil medapat persentase $91,1 \%$ masuk kriteria sangat layak, uji coba kelompok besar mendapat persentase 97,82\% masuk kriteria sangat layak, penilaian guru uji coba kelompok kecil mendapat persentase 98,3\% masuk kriteria sangat layak, dan penilaian guru uji coba kelompok besar mendapat persentase $100 \%$ masuk kriteria sangat layak. Berdasarkan data tersebut, bahan ajar LKS berbasis Contextual Teaching and Learning yang dikembangkan layak digunakan dalam proses pembelajaran

Kata kunci: LKS, Kontekstual, IPA.

\section{PENDAHULUAN}

Bahan ajar di dalam dunia pendidikan memiliki peran penting. Sudah banyak berbagai macam bahan ajar di dalam dunia pendidikan.. Bahan ajar sangat diperlukan dalam dunia pendidikan karena bahan ajar dapat membantu dalam memecahkan masalah yang ada. Menurut Prastowo (2012) bahan ajar adalah sekumpulan dari bahan-bahan berbagai materi pelajaran yang disusun secara sistematis yang digunakan dalam proses pembelajaran oleh siswa dan guru untuk mendapat informasi misalnya LKS. Bahan ajar juga banyak digunakan di sekolah oleh guru, terutama sekolah dasar untuk menyampaikan materi kepada siswa

Salah satu pembelajaran di sekolah dasar yaitu terdapat mata pelajaran Ilmu Pengetahuan Alam (IPA). Pembelajaran IPA termasuk pembelajaran yang menyenangkan karena berhubungan langsung dengan alam sekitar. IPA mempunyai hakikat sebagai ilmu pengetahuan yang berkaitan dengan gejala alam yang dapat dituangkan berupa fakta, prinsip, dan konsep yang diuji melalui suatu rangkaian kegiatan percobaan.

Proses pembelajaran IPA lebih menekankan cara belajar secara langsung yang bermaksud siswa dapat menentukan suatu fakta, prinsip, dan konsep sehingga materi akan mudah diingat. Melalui mata pelajaran IPA, kerja ilmiah seperti melakukan pengamatan, memprediksi, dan keterampilan berpikir dapat dilatihkan kepada siswa dalam usaha memberi bekal ilmu pengetahuan.

Menurut Susanto (201) mengatakan Sains atau IPA adalah usaha manusia untuk memahami alam semesta melalui pengamatan serta menggunakan prosedur dan menggunakan penalaran untuk menyimpulkan suatu pengetahuan yang telah dipelajari. Oleh sebab itu ilmu pengetahuan alam di sekolah seharusnya dapat memberikan pembelajaran bagi siswa untuk memahami diri sendiri dan alam yang kemudian dapat diterapkan dalam kehidupan sehari-harinya. Maka seseorang guru harus mampu 
menyampaikan materi pembelajaran IPA kepada siswa sehingga siswa dapat menerapkan ilmu yang diperoleh dari pembelajaran IPA ke dalam kehidupan sehari-harinya.

Berdasarkan dari pengamatan yang telah dilakukan di SD Muhammadiyah Pakel Program Plus Yogyakarta dapat diketahui bahwa siswa masih kurang dalam memahami pelajaran IPA. Siswa cenderung bosan pada saat proses pembelajaran IPA, hal itu terjadi karena guru dalam penyampaian materi masih dominan menggunakan metode ceramah. Penggunaan metode tersebut membuat siswa menjadi bersifat pasif dimana siswa hanya diam dan duduk mendengarkan penjelasan dari guru. Selain itu guru cenderung hanya menggunakan buku paket sebagai bahan ajar siswa. Dalam suatu proses pembelajaran siswa pasti akan sulit untuk memahami materi yang hanya disajikan menggunakan metode ceramah dan tertulis saja. Siswa membutuhkan proses pembelajaran yang mampu menstimulasi semua indera pandang dan indera dengar. Dalam pembelajaran IPA, siswa membutuhkan pengamatan, salah satu pendekatan yang cocok untuk pendekatan pembelajaran IPA adalah pendekatan kontekstual.

CTL (Contextual Teaching and Learning) adalah sistem pembelajaran yang sesuai dengan kinerja otak, untuk menyusun pola-pola yang mewujudkan makna, dengan cara menghubungkan muatan akademis dengan konteks kehidupan sehari-hari siswa. Hal ini penting diterapkan agar informasi yang diterima tidak hanya disimpan dalam memori jangka pendek, yang mudah dilupakan, tetapi dapat disimpan dalam memori jangka panjang sehingga akan dihayati dan diterapkan dalam tugas pekerjaan. CTL (Contextual Teaching and Learning) disebut pendekatan kontekstual karena konsep belajar yang membantu guru mengaitkan antara materi yang diajarkanya dengan situasi dunia nyata siswa dan mendorong siswa membuat hubungan antara pengetahuan dengan kehidupan nyata. (Yamin, 2013).

Selain menggunakan pendekatan pembelajaran yang sesuai, dalam meningkatkan mutu pendidikan selain perkembangan Kurikulum Tingkat Satuan Pendidikan (KTSP), maka perlu dikembangkan juga bahan ajar berupa Lembar Kerja Siswa (LKS). Penggunaan bahan ajar dalam pembelajaran mempunyai peranan penting. Untuk mengembangkan bahan ajar yang diinginkan maka guru memiliki langkah-langkah yang harus diketahui sehingga dapat menciptakan bahan ajar yang baik dan berkualitas. Pengembangan LKS dapat memudahkan dalam pelajaran IPA. LKS yang dikembangkan berisi gambar-gambar yang sesuai dengan materi agar siswa dapat dengan mudah memahami materi IPA. Tetapi peran guru tidak dihilangkan dalam kegiatan pembelajaran. LKS yang dikembangkan akan membuat siswa jadi lebih aktif dalam belajar dan menggali ilmu tentang IPA.

LKS yang dikembangkan oleh guru masih kurang menarik. Hal ini dilihat dari cover dan isi yang ada. Tampilan cover tidak berisi gambar yang menarik melainkan hanya tulisan LKS saja dan isi yang disajikan hanya kegiatan siswa yang bentuknya sederhana. Siswa hanya dituntut untuk menjawab soal-soal yang telah disajikan tanpa ada pemahaman konsep materi yang diajarkan secara benar. Soal-soal yang disajikan pada LKS IPA cenderung monoton sehingga tampilan kurang menarik. Hal inilah yang menimbulkan pembelajaran yang membosankan bagi siswa. Selain itu LKS IPA yang digunakan siswa belum maksimal dalam hal mengamati di lingkungan sekolah. Lingkungan sekolah memang memiliki pengaruh terhadap proses belajar peserta didik dan pendidik dalam melaksanakan proses pembelajaran seperti pernyataan dari Atwool dalam Daryanto (2015) menyatakan "bahwa lingkungan pembelajaran sekolah, di mana siswa mempunyai kesempatan untuk melakukan hubungan yang bermakna didalm lingkungan sekolahnya, sangat diperlukan untuk meningkatkan kemampuan belajar siswa, memfasilitasi siswa 
untuk bertingkah laku yang sopan, serta berpotensi untuk membantu siswa dalam menghadapi masalah yang dibawa dari rumah".

Lingkungan sekolah merupakan lingkungan yang berpengaruh dan bermakna bagi siswa dalam proses belajar mengajar yang ada di sekolah. Baik itu dalam lingkungan sosial maupun lingkungan nonsosial. Lingkungan sekolah meliputi lingkungan fisik sekolah seperti lingkungan kampus/sekolah, sarana dan prasarana belajar yang ada, sumber-sumber belajar, media belajar seterusnya, lingkungan sosial yang menyangkut hubungan siswa dengan teman-temanya, guru-gurunya serta staf sekolah yang lain. (Wahyuningsih, 2013). Berdasarkan uraian diatas dapat diketahui bahwa pembelajaran saat ini belum dapat berlangsung secara maksimal karena belum tersedianya LKS kontekstual berisi gambargambar yang menarik sebagai pendukung proses kegiatan belajar mengajar. Sehingga guru memerlukan sebuah pembelajaran yang kontekstual, oleh karena itu pada kesempatan ini peneliti hendak melakukan penelitian dengan judul "Pengembangan Lembar Kerja Siswa (LKS) Berbasis Contextual Teaching and Learning di Lingkungan Sekolah Pada Mata Pelajaran IPA Kelas III SD Muhammadiyah Pakel Program Plus Yogyakarta”. Tujuan utama dari penelitian ini adalah untuk mengetahui pengembangan lembar kerja siswa (LKS) berbasis contextual teaching and learning di lingkungan sekolah pada mata pelajaran IPA kelas III SD Muhammadiyah Pakel Program Plus Yogyakarta, Mengetahui kelayakan pengembangan lembar kerja siswa (LKS) berbasis contextual teaching and learning di lingkungan sekolah pada mata pelajaran IPA kelas III SD Muhammadiyah Pakel Program Plus Yogyakarta, dan mengetahui bagaimana keefektifan pembelajaran IPA kelas III SD Muhammadiyah Pakel Program Plus dengan bahan ajar LKS berbasis Contextual Teaching and Learning di lingkungan sekolah..

Ilmu Pengetahuan Alam (IPA) adalah ilmu yang mempelajari alam tentang mahluk hidup, air, tanah, udara, dan zat. Trianto (2010) mengemukakan "IPA adalah suatu kumpulan yang sistematis, penerapanya secara umum terbatas pada gejala-gejala alam, lahir dan berkembang melalui metode ilmiah seperti oobservasi dan eksperimen serta menuntut sikap ilmiah seperti rasa ingin tahu, terbuka, jujur, dan sebagainya". Sesuai dengan pernyataan Wahyana dalam Trianto (2010) mengatakan bahwa "IPA adalah suatu sekumpulan pengetahuan yang terususun secara sistematik, dan dalam penggunaanya secara umum terbatas pada gejala-gejala alam”. Kemudian Kardi dan Nur dalam Trianto (2010: 136) mengatakan bahwa "IPA atau ilmu kealaman adalah ilmu tentang dunia zat, baik mahluk hidup maupun benda mati yang diamati".

Pendidikan IPA telah diajarkan di sekolah sejak sekolah dasar hingga sekolah menengah. Oleh sebab itu pendidikan IPA disekolah dasar harus dikemas dengan baik agar ilmu yang disampaikan kepada siswa bisa bermanfaat dengan baik. Selain itu agar pengetahuan siswa tentang IPA menjadi luas dan bisa bermanfaat bagi masa depan siswa.

Lembar kerja siswa (Student Work Sheet) adalah lembaran-lembaran berisi tugas yang harus dikerjakan oleh peserta didik. Lembar kerja siswa akan memuat paling tidak; judul, KD yang akan dicapai, waktu penyelesaian, peralatan atau bahan yang diperlukan untuk menyelesaikan tugas, informasi singkat, langkah kerja, tugas yang harus dilakukan, dan laporan yang harus dikerjakan. Depdiknas (2008). Fitriyati, dkk (2013) mengemukakan pengertian LKS yaitu "LKS merupakan lembaran-lembaran yang berisi tugas yang harus dikerjakan oleh peserta didik untuk melakukan kegiatan agar mereka memperoleh pengetahuan dan keterampilan yang perlu dikuasai secara mandiri".

Kelayakan LKS meliputi 4 komponen diantaranya yaitu kelayakan isi, komponen kebahasaan, komponen penyajian, dan komponen kegrafikan sesuai dengan Depdiknas (2008) yaitu sebagai berikut, komponen kelayakan isi, komponen kebahasaan, komponen 
penyajian, dan komponen kegrafikan. LKS memiliki beberapa fungsi, fungsi LKS menurut Prastowo (2012) fungsi LKS diantaranya yaitu sebagai berikut, sebagai bahan ajar yang bisa meminimalkan peran guru, namun lebih mengaktifkan siswa dalam kegiatan pembelajaran, sebagai bahan ajar yang dapat mempermudah siswa dalam memahami dan menguasai materi pembelajaran yang diberikan oleh guru, sebagai bahan ajar yang ringkas dan kaya akan berbagai tugas untuk berlatih siswa dalam belajar, dan untuk memudahkan pelaksanaan pengajaran kepada siswa sehingga guru tidak kewalahan dalam menyampaikan materi pelajaran.

LKS mempunyai kegunaan bagi kegiatan pembelajaran. Menurut Prastowo (201) LKS memiliki banyak kegunaan pada saat kegiatan pembelajaran berlangsung. Kegunaan bagi guru, salah satu kegunaan bagi guru yaitu agar siswa secara aktif dapat terlibat dalam proses pembelajaran, kegunaan LKS bagi guru adalah sebagai bahan ajar yang dapat digunakan untuk mempermudah guru dalam menyampaikan materi pelajaran kepada siswa pada saat proses pembelajaran berlangsung, kemudian agar siswa dapat secara maksimal memahami materi yang telah disampaikan oleh guru. Shoimin (2014) mengemukakan pendapatnya, Contextual Teaching and Learning merupakan suatu proses pembelajaran yang holistik yang memiliki tujuan untuk memotivasi siswa memahami materi yang dipelajari oleh siswa dengan mengaiktan materi tersebut dengan konteks kehidupan seharihari yang dialami. Kesuma, dkk (2010) mengemukakan "CTL" adalah mengajar dan belajar yang menghubungkan isi pelajaran dengan lingkungan". Jonshon (2014) berpendapat bahwa "CTL adalah sebuah sistem belajar yang didasarkan pada filosofi bahwa siswa mampu menyerap pelajaran apabila mereka menangkap makna dalam materi akademis yang mereka terima, dan mereka menangkap makna dalam tugas-tugas sekolah jika mereka bisa mengaitkan informasi baru dengan pengetahuan dan pengalaman yang sudah mereka miliki sebelumnya"

Menurut Suprijono (2009) pembelajaran kontekstual atau CTL yaitu merupakan konsep yang membantu guru untuk mengaitkan materi yang diajarkan dengan situasi di dunia nyata agar dapat mendorong siswa menghubungkan pengetahuan dengan kehidupan yang dialami oleh siswa. Hajir, dkk (2012) mengemukakan pendapat mengenai proses pembelajaran kontekstual yaitu "Model CTL dalam proses pembelajaran dimana siswa aktif menemukan materi yang dipelajari dan ada hubunganya dengan lingkungan nyata dimana siswa berada sehingga dapat diterapkan dalam kehidupannya.

Yamin (2013) mengemukakan tentang tujuan pembelajaran kontekstual untuk membantu siswa memahami materi pelajaran dan menghubungkan dengan kehidupannya sehari-hari seperti, membuat hubungan antara subjek dengan pengalaman yang telah dialami di kehidupan nyata, siswa mampu melakukan pekerjaan atau tugas yang sesuai, siswa melakukan pembelajaran yang diatur sendiri, siswa saling bekerjasama dalam satu kelompok, siswa mampu berpikir kritis dan kreatif, siswa menjaga dan mempertahankan kemajuan pertumbuhan, siswa menjadi mandiri, dan produktif.

Shoimin (2014) mengemukakan keunggulan CTL ini adalah sebagai berikut, dapat menekan cara berpikir siswa secara utuh baik secara fisik maupun secara mental, dapat menjadikan siswa belajar bukan menghafal sesuai apa yang dialami dengan kehidupan nyata, kelas dalam kontekstual bukan tempat untuk memperoleh informasi, tetapi tempat untuk menguji data dari hasil yang ditemukan dilapangan, dan materi pembelajaran yang dipelajari ditentukan oleh siswa. Pendekatan CTL pada pembelajaran IPA bertujuan untuk berusaha mengubah kegiatan pembelajaran dengan membuat skenario pembelajaran dimulai dari konteks kehidupan nyata siswa kemudian guru memfasilitasi siswa untuk 
mengangkat objek dalam kehidupan nyata kedalam konsep IPA. Sehingga siswa dapat memecahkan masalah tersebut dengan bimbingan guru.

Karwati dan Priansa (2014) mengatakan lingkungan sekolah yaitu semua kondisi di sekolah yang dapat mempengaruhi tingkah laku warga sekolah terutama guru dan peserta didik sebagai ujung tombak dalam kegiatan pembelajaran di lingkungan sekolah, lingkungan sekolah juga akan mempengaruhi tumbuh kembangnya kualitas guru dan siswa.

Lingkungan sekolah memang memiliki pengaruh terhadap proses belajar siswa dan guru dalam melaksanakan proses pembelajaran seperti pernyataan dari Atwool dalam Daryanto (2015) menyatakan "Bahwa lingkungan pembelajaran sekolah, dimana siswa mempunyai kesempatan untuk melakukan hubungan yang bermakna di dalam lingkungan sekolahnya, sangat diperlukan untuk meningkatkan kemampuan belajar siswa, memfasilitasi siswa untuk bertingkah laku yang sopan, serta berpotensi untuk membantu siswa dalam menghadapi masalah yang dibawa dari rumah".

Papanastaiou (Daryanto, 2015) menyatakan bahwa secara langsung maupun tidak langsung, lingkungan sekolah dapat memberikan efek kepada siswa pada saat siswa belajar dengan guru didalam proses pembelajaran kususnya pada mata pelajaran IPA. Lingkungan sekolah memang memiliki keterkaitan dengan pembelajaran IPA, karena pada hakikatnya ilmu IPA yaitu ilmu yang mempelajari tentang alam yang memerlukan pengamatan serta penalaran sesuai dengan pernyataan dari Susanto (2013) mengemukakan Sins atau IPA adalah usaha manusia untuk memahami alam semesta melalui pengamatan serta menggunakan prosedur dan menggunakan penalaran untuk menyimpulkan suatu pengetahuan yang telah dipelajari. Hamdani (2011) mengemukakan pendapat mengenai manfaat lingkungan "Pemanfaatan lingkungan dapat mengembangkan sejumlah keterampilan, seperti mengamati (dengan seluruh indra), mencatat, merumuskan pertanyaan, berhipotesis, mengklasifikasi, membuat tulisan, dan membuat gambar atau diagram".

\section{METODE PENELITIAN}

Penelitian ini adalah jenis penelitian pengembangan atau Research and Development (R\&D). Produk yang akan dikembangankan dalam penelitian ini adalah Lembar Kerja Siswa (LKS) berbasis Contextual Teaching and Leaarning di lingkungan sekolah. Terdapat lima tahapan yang dilakukan peneliti untuk uji coba produk agar produk dianggap layak diantaranya yaitu : desain uji coba, subjek coba, jenis data, instrument pengumpulan data, dan teknik analisis data. Desain uji coba penellitian ini dilakukan dengan menyusun dan mengembangkan LKS IPA materi menjaga kesehatan lingkungan sekitar. Uji coba ini dilakukan agar mendapat respon untuk perbaikan produk. Uji coba produk ini melewati tahap uji validasi kepada dosen ahli untuk menilai LKS pada aspek media, materi dan pembelajaran. Kemudian dilakukan uji coba kepada siswa dalam kelompok kecil maupun besar. Kemudian siswa akan diberi angket untuk menilai LKS berbasis CTL. Subjek uji coba dalam penelitian pengembangan LKS yaitu uji coba ahli yang terdiri dari ahli media, ahli materi, ahli pembelajaran, kemudian siswa SD yang terdiri dari kelompok kecil yang berjumlah 6 orang siswa dan kelompok kecil yang terdiri dari 24 orang siswa.

Jenis data yang digunakan dalam penelitian pengembangan LKS IPA berbasis CTL adalah data kualitatif dan data kuantitatif. Data kualitatif ini berupa hasil kritikan dan saran dari dosen ahli, guru, dan siswa yang didapat dari angket penilaian, selanjutnya data tersebut digunakan untuk revisi produk yang dikembangkan. Data kuantitatif ini berupa 
penilaian yang diperoleh dari dosen ahli, guru dan siswa. Seluruh data yang telah diperoleh akan digunakan untuk mengukur suatu produk dan menilai kelayakan suatu produk dengan angka.

Pengumpulan data penelitian pengembangan ini menggunakan lembar angket. Instrumen penilaian ini untuk penguji ahli, guru dan siswa. Lembar angket penelitian diberikan kepada ahli media, ahli materi, dan ahli pembelajaran pada saat uji validasi, kepada guru dan siswa pada saat uji coba produk ini. Lembar angket diberikan kepada ahli media, guru, dan siswa guna mendapat penilaian, komentar, dan saran berdasarkan pengamatan, sehingga lembar angket yang diberikan dapat digunakan sebagai pedoman perbaikan produk agar produk yang dikembangkan menjadi semakin baik dan layak untuk digunakan.

Penelitian pengembangan Lembar Kerja Siswa berbasis Contextual Teaching and Lerning, peneliti menggunakan teknik analisis data kualitatif dan kuantitatif untuk mengolah data yang diperoleh. Analisis data ini dilakukan dengan mengelompokkan informasi-informasi data kualitatif berupa tanggapan, masukan, serta saran dari uji ahli dan lembar angket guru, dan angket siswa. Selanjutnya hasil analisis data kualitatif dijadikan pertimbangan untuk melakukan revisi produk. Analisis data kuantitatif ini digunakan untuk mengolah data yang diperoleh dari hasil pengisian lembar angket oleh penguji ahli media, ahli materi, ahli pembelajaran, angket guru dan angket siswa. Angket validasi ahli diukur dengan menggunakan skala Likert yang mempunyai kategori rentan nilai yang tertinggi sampai nilai terendah. Rentan skor yang digunakan adalah dalam bentuk angka $(4,3,2,1)$.

\section{HASIL DAN PEMBAHASAN}

Tahap potensi dan masalah ini peneliti melakukan pengamatan di SD Muhammadiyah Pakel Program Plus Yogyakarta. Hasil pengamatan yang diperoleh dikelas masih cenderung pasif ketika proses pembelajaran khususnya IPA, pembelajaran cenderung hanya terfokus pada buku pelajaran serta papan tulis ketika proses pembelajaran. Hasil pengamatan yang telah dilakukan, maka potensi yang ada di SD Muhammadiyah Pakel Program Plus Yogyakarta ini belum tersedianya bahan ajar LKS berbasis Contextual Teaching and Learning. Berdasarkan pemaparan hasil pengamatan maka peneliti melakukan pengembangan bahan ajar LKS berbasis Contextual Teaching and Learning untuk pembelajaran IPA pada materi menjaga kesehatan lingkungan Sekitar.

Mengumpulkan informasi data. Bahan ajar LKS berbasis Contextual Teaching and Learning ini merupakan bahan ajar yang dikembangakan pada mata pelajaran IPA materi menjaga kesehatan lingkungan sekitar. Pengumpulan data dilakukan pada penelitian ini adalah mencari referensi buku yang berkaitan dengan materi menjaga kesehatan lingkungan sekitar, metode pembelajaran yaitu pendekatan kontekstual agar dapat digunakan untuk mengatasi masalah dalam kegiatan pembelajaran IPA materi menjaga kesehatan lingkungan sekitar. Sehingga LKS berbasis Contextual Teaching and Learning ini dapat menjadi salah satu bahan ajar untuk membantu siswa memahami materi menjaga kesehatan lingkungan sekitar karena materi dalam LKS dikaitkan dengan kehidupan nyata.

Desain produk. Menentukan SK, KD dan Indikator yang disajikan, mencari referensi materi dan soal untuk penyusunan LKS, membuat desain tampilan LKS, proses pembuatan cover sendiri dibuat menggunakan Software CorelDraw X7 yang dicetak menggunakan kertas jenis Ivory 230 ukuran A4. Hal ini bertujuan agar mendapatkan desain gambar yang sempurna dari segi gambar serta warna, karena menggunakan Sofware CorelDraw $X 7$ merupakan langkah yang tepat dalam mendesain cover 
Produk media yang dikembangkan divalidasi oleh ahli media, validasi materi dan validasi pembelajaran. Penguji ahli dilakukan oleh Ibu Amaliyah Ulfah, M.Pd sebagai validator instrumen, Bapak Lovandri Dwanda P., M.Pd sebagai validator media, Ibu Ika Maryani, M.Pd sebagai validator materi dan Ibu Siwi Purwanti, M.Pd sebagai validator pembelajaran. selain itu, penilaian berdasarkan angket respon siswa dan lembar penilaian guru terhadap bahan ajar LKS berbasis Contextual Teaching and Learning. Data hasil penilaian ahli, uji coba produk kelompok kecil dan uji coba pemakaian kelompok besar tersebut berupa data kualitatif dan kuantitatif. Data ini diperoleh berdasarkan pengisian angket, masukan atau saran untukpenyempurnaan bahan ajar yang dikembangkan. Penilaian validasi ahli media terhadap kualitas produk bahan ajar LKS berbasis Contextual Teaching and Learning ini dilakukan oleh Bapak Lovandri Dwanda P., M.Pd sebagai dosen validasi media. Penilaian bahan ajar LKS berbasis Contextual Teaching and Learning ini dilakukan pada tanggal 11 September 2017 bertempat di ruang dosen gedung baru PGSD kampus V UAD. Berdasarkan uji coba ahli media yang telah dilakukan, maka penilaian mendapat jumlah skor 56 dengan persentase penilaian 93,3\%. Apabila persentase tersebut jika dilihat berdasarkan konversi data kuantitatif ke data kualitatif, maka bahan ajar LKS berbasis Contextual Teaching and Learning yang dikembangkan kategori Sangat Layak

Penilaian validasi ahli materi terhadap kualitas produk bahan ajar LKS berbasis Contextual Teaching and Learning ini dilakukan oleh Ibu Ika Maryani, M.Pd sebagai dosen validasi materi. Penilaian bahan ajar LKS berbasis Contextual Teaching and Learning ini dilakukan pada tanggal 11 September 2017 bertempat di gedung baru PGSD kampus V UAD. Penilaian mendapat jumlah skor 49 dengan persentase penilaian 81,67\%. Apabila persentase tersebut jika dilihat berdasarkan konversi data kuantitatif ke data kualitatif, maka bahan ajar LKS Berbasis Contextual Teaching and Learning yang dikembangkan berkriteria Sangat Layak. Penilaian validasi ahli ini dilakukan oleh Ibu Siwi Purwanti, M.Pd sebagai dosen validasi pembelajaran. Penilaian bahan ajar LKS berbasis Contextual Teaching and Learning ini dilakukan pada tanggal 11 September 2017. Berdasarkan uji coba ahli pembelajaran yang telah dilakukan, maka penilaian mendapat jumlah skor 48 dengan persentase penilaian $80 \%$. Apabila persentase tersebut jika dilihat berdasarkan konversi data kuantitatif ke data kualitatif, maka bahan ajar LKS berbasis Contextual Teaching and Learning yang dikembangkan berkriteria Layak. Dari hasil validasi ketiga ahli dapat disimpulkan sebagai berikut, ahli media 93,3\%, ahli materi $81,67 \%, 80 \%$, jika dijumlahkan yaitu $254,97 \%$ maka rata-ratanya adalah $84,99 \%$, apabila dikonversikan ke dalam data kualitatif secara keseluruhan hasil dari ketiga validator yaitu masuk kategori sangat layak.

Uji coba produk pada kelompok kecil ini dilakukan di SD Muhammadiyah Pakel Program Plus Yogyakarta pada tanggal 13 September 2017. Uji coba kelompok kecil ini terdiri dari 6 orang siswa, diketahui jumlah skor 328 sehingga persentase 91,1\%. Apabila nilai presentase tersebut dikonversikan ke dalam data kualitatif maka bahan ajar LKS berbasis CTL termasuk ke dalam kriteria Sangat Layak. Penilaian bahan ajar LKS berbasis Contextual Teaching and Learning ini dilakukan oleh guru kelas III A yaitu Bapak Purwahid, S.Ag. Hasil penilaian guru diketahui skor 59 sehingga persentase 98,3\%, Apabila nilai persentase tersebut dikonversikan kedalam data kualitatif maka bahan ajar LKS berbasis Contextual Teaching and Learning termasuk ke dalam kriteria Sangat Layak. Seluruh nilai persentase yang didapat dari peserta didik dan guru pada uji coba produk kelompok kecil kemudian dikonversikan ke dalam data kualitatif yaitu jumlah 
keseluruhan $189 \%$ maka rata-rata yang diperoleh adalah 94,7\% masuk kriteria sangat layak.

Uji coba produk pada kelompok besar ini dilakukan di SD Muhammadiyah Pakel Program Plus Yogyakarta pada 14 September 2017. Uji coba kelompok besar ini terdiri dari 24 orang siswa, tetapi pada saat melakukan uji coba pemakaian kelompok besar ada 1 siswa yang tidak berangkat ke sekolah karena sakit. Hasil penilaian respon siswa diketahui jumlah skor 1350 sehingga persentase 97,82\%. Apabila nilai persentase tersebut dikonversikan ke dalam data kualitatif maka bahan ajar LKS berbasis CTL termasuk ke dalam kategori Sangat Layak. Hasil penilaian respon guru terhadap bahan ajar LKS berbasis Contextual Teaching and Learning pada mata pelajaran IPA pada materi Menjaga Kesehatan Lingkungan Sekitar kelas III yang sudah dikembangkan. Penilaian bahan ajar LKS berbasis Contextual Teaching and Learning ini dilakukan oleh guru kelas III A yaitu Bapak Purwahid, S.Ag. Hasil penilaian guru diketahui skor 60 sehingga persentase $100 \%$. Apabila nilai persentase tersebut dikonversikan kedalam data kualitatif maka bahan ajar LKS berbasis Contextual Teaching and Learning termasuk ke dalam kategori Sangat Layak.

Berdasarkan dari seluruh nilai persentase yang didapat dari peserta didik dan guru dari hasil uji coba pemakaian kelompok besar, hasil konversi uji coba kelompok besar adalah sebagai berikut, respon siswa 97,82\% kemudian respon guru 100\%. Maka apabila dikonversikan kedalam data kualitatif secara keseluruhan bahan ajar LKS berbasis Contextual Teaching and Learning termasuk ke dalam kategori Sangat Layak. Analisis data kuantitatif digunakan untuk mengolah data yang diperoleh dari pengisian lembar angket ahli media, ahli materi, ahli pembelajaran, respon siswa dan guru terhadap bahan ajar LKS berbasis Contextual Teaching and Learning di lingkungan sekolah pada mata pelajaran IPA materi menjaga kesehatan lingkungan sekitar

\section{SIMPULAN}

Berdasarkan hasil penelitian dan pengembangan bahan ajar LKS berbasis Contextual Teaching and Learning di lingkungan sekolah untuk mata pelajaran IPA materi menjaga kesehatan lingkungan sekitar kelas III SD Muhammadiyah Pakel Program Plus Penelitian dan pengembangan yang dilakukan sesuai dengan langkah-langkah yang direncanakan, dimulai dari potensi masalah, pengumpulan data, desain produk, validasi desain, revisi desain, uji coba produk, revisi produk, uji coba pemakaian, revisi produk, sampai produksi masal, sehingga dihasilkan bahan ajar LKS berbasis Contextual Teaching and Learning di lingkungan sekolah pada mata pelajaran IPA materi menjaga kesehatan lingkungan sekitar kelas III SD Muhammadiyah Pakel Program Plus Yogyakarta.

Bahan ajar LKS berbasis Contextual Teaching and Learning di lingkungan sekolah pada mata pelajaran IPA materi menjaga kesehatan lingkungan sekitar kelas III SD Muhammadiyah Pakel Program Plus Yogyakarta, dinyatakan Sangat Layak untuk digunakan sebagai bahan ajar pada mata pelajaran IPA. Hal ini berdasarkan penilaian dari 3 pakar ahli, siswa dan guru sebagai berikut. 1)Hasil penilaian para ahli, bahan ajar LKS berbasis Contextual Teaching and Learning di lingkungan sekolah oleh ahli media yaitu Bapak Lovandri Dwanda P., M.Pd mendapatkan persentase 93,3\% dengan kategori Sangat Layak. Penilaian ahli materi oleh Ibu Ika Maryani, M.Pd mendapatkan persentase 81,67\% dengan kategori Sangat Layak. Penilaian ahli pembelajaran oleh Ibu Siwi Purwanti M.Pd mendapatkan persentase $80 \%$ sehingga termasuk dalam kategori Layak. 2) Hasil uji coba produk kelompok kecil di SD Muhammadiyah Pakel Program Plus Yogyakarta penilaian 
angket respon siswa adalah 91,1\% dengan kategori Sangat Layak. Kemudian, pada penilaian guru adalah 98,3\% termasuk dalam kategori Sangat Layak. Selanjutnya kedua penilaian dicari rata-rata penilaian uji coba produk dan hasilnya adalah 94,7\% termasuk dalam kategori Sangat Layak. 3) Hasil uji coba kelompok besar di SD Muhammadiyah Pakel Program Plus Yogyakarta penilaian angket respon siswa adalah 97,82\% dengan kategori Sangat Layak. Kemudian pada penilaian guru adalah $100 \%$ termasuk dalam kategori Sangat Layak. Selanjutnya dari kedua penilaian tersebut dicari rata-rata penilaian uji coba pemakaian dan hasilnya adalah 98,91\% sehingga bahan ajar LKS berbasis Contextual Teaching and Learning di lingkungan sekolah termasuk dalam kategori Sangat Layak.

\section{DAFTAR PUSTAKA}

Daryanto. 2014. Pengembangan Perangkat Pembelajaran. Yogyakarta: Gava Media.

Daryanto. 2015. Pengelolaan Budaya dan Iklim Sekolah. Yogyakarta: Gava Media.

Departemen Pendidikan Nasional. 2008. Panduan Pengembangan Bahan Ajar.

Fitriyati. 2013. Pengmbangan LKS Fisika SMA Kelas X Semester II dengan Website Online Berbasis Contextual Teaching Learning. Pendidikan Fisika , (1). 2.

Hajir.2012. Penerapan Pembelajaran Contextual Teaching and Learning (CTL) Untuk Peningkatan Pemahaman IPA Siswa Kelas IV Sekolah Dasar Negeri 2 Wonosari Sadang . Pendidikan Fisika, (2). 2.

Hamalik, Oemar. 2013. Kurikulum dan Pembelajaran. Jakarta: Bumi Aksara.

Jhonson. 2014. CTL Contextual Teaching \& Learning. Bandung: Penerbit Kaifa.

Kesuma, D. 2010. Contextual Teaching and Learning. Garut: RAHAYASA Research and Training.

Prastowo, A. 2012. Panduan Kretif Membuat Bahan Ajar Inovatif. Yogyakarta: Diva Press.

Priansa, E. K. 2014. Manajemen Kelas (Classroom Management). Bandung: Alfabeta

Shoimin. 2014. 68 Model Pembelajaran Inovatif dalam Kurikulum 2013. Yogyakarta: ARRUZZ MEDIA.

Suprijono, Agus. 2009 . Cooperative Learning Teori \& Aplikasi Paikem. Yogyakarta: Pustaka Belajar.

Susanto, A. 2013. Teori Belajar \& Pembelajaran di Sekolah Dasar. Jakarta: PRENADAMEDIA GROUP.

Trianto. 2010. Model Pembelajaran Terpadu. Jakarta: Bumi Aksara. 
Wahyuningsih, S. 2013. Pengaruh Lingkungan Sekolah dan Kebiasaan Belajar Terhadap Prestasi Belajar Akuntansi Siswa Kelas XI IPS SMA Negeri 1 Srandakan. Kajian Pendidikan \& Akuntansi Indonesia, 1, (2) , 2-3.

Yamin, M. 2013. Strategi \& Metode dalam Model Pembelajaran . Jakarta: Referensi (GP Press Group). 